\title{
Lead-Free Halide Double Perovskites: A Review of the Structural, Optical, and Stability Properties as Well as Their Viability to Replace Lead Halide Perovskites
}

\author{
Edson Meyer ${ }^{1}$, Dorcas Mutukwa ${ }^{1,2, *(\mathbb{D})}$, Nyengerai Zingwe ${ }^{1,2}$ and Raymond Taziwa ${ }^{1}$ \\ 1 Fort Hare Institute of Technology, University of Fort Hare, Alice 5700, South Africa; \\ emeyer@ufh.ac.za (E.M.); nzingwe@ufh.ac.za (N.Z.); rtaziwa@ufh.ac.za (R.T.) \\ 2 Department of Chemistry, University of Fort Hare, Alice 5700, South Africa \\ * Correspondence: dmutukwa@ufh.ac.za; Tel.: +27-61-686-8252
}

Received: 12 July 2018; Accepted: 9 August 2018; Published: 27 August 2018

\begin{abstract}
Perovskite solar cells employ lead halide perovskite materials as light absorbers. These perovskite materials have shown exceptional optoelectronic properties, making perovskite solar cells a fast-growing solar technology. Perovskite solar cells have achieved a record efficiency of over 20\%, which has superseded the efficiency of Gräztel dye-sensitized solar cell (DSSC) technology. Even with their exceptional optical and electric properties, lead halide perovskites suffer from poor stability. They degrade when exposed to moisture, heat, and UV radiation, which has hindered their commercialization. Moreover, halide perovskite materials consist of lead, which is toxic. Thus, exposure to these materials leads to detrimental effects on human health. Halide double perovskites with $\mathrm{A}_{2} \mathrm{~B}^{\prime} \mathrm{B}^{\prime \prime} \mathrm{X}_{6}\left(\mathrm{~A}=\mathrm{Cs}, \mathrm{MA} ; \mathrm{B}^{\prime}=\mathrm{Bi}, \mathrm{Sb} ; \mathrm{B}^{\prime \prime}=\mathrm{Cu}, \mathrm{Ag}\right.$, and $\mathrm{X}=\mathrm{Cl}, \mathrm{Br}$, I) have been investigated as potential replacements of lead halide perovskites. This work focuses on providing a detailed review of the structural, optical, and stability properties of these proposed perovskites as well as their viability to replace lead halide perovskites. The triumphs and challenges of the proposed lead-free $\mathrm{A}_{2} \mathrm{~B}^{\prime} B^{\prime \prime} \mathrm{X}_{6}$ double perovskites are discussed here in detail.
\end{abstract}

Keywords: perovskite solar cells; halide double perovskites; light absorbers; bandgap; optoelectronic

\section{Introduction}

Perovskite solar cells (PSCs) constitute a new emerging low-cost solar technology that has the potential to dominate or co-exist with silicon solar technologies [1]. PSCs have sparked major interest in the photovoltaic community due to their remarkable photon conversion efficiency, which has increased from $3.8 \%$ to $22.7 \%$ [2] in less than 10 years, as compared to their predecessors, DSSCs. DSSCs have only managed to reach an efficiency of $11.9 \%$ over two decades of research. PSCs employ perovskite materials as light-harvesting materials. These perovskite materials have shown remarkable photovoltaic properties such as long charge diffusion length, direct bandgap, tunable bandgap, low carrier recombination, high carrier mobilities, high molar extinction coefficient, and strong absorption in the visible spectrum [3,4].

PSCs consist of (1) an organic-inorganic metal halide perovskite light harvester e.g., $\mathrm{CH}_{3} \mathrm{NH}_{3} \mathrm{PbI}_{3}\left(\mathrm{MAPbI}_{3}\right)$, (2) a hole-transporting material (HTM), e.g., spiroMeOTAD (2,2'7,7'-tetrakis(N,N-di-p-methoxyphenylamine)-9,9'-spiro-bifluorene), (3) an electron-transporting material (ETM), e.g., [6,6]-phenyl-C61-butyric acid methyl ester (PCBM), (4) a transparent conducting electrodes, e.g., an indium tin oxide (ITO) or fluorine-doped tin oxide (FTO) electrode, (5) a back contact, e.g., Au, and (6) a mesoporous layer of $\mathrm{TiO}_{2}$ nanoparticles for mesoscopic cells. The PSC device configurations 
can be classified into mesoporous and planar heterojunction devices; further classification introduces the $n-i-p$ and $p-i-n$ devices as shown in Figure 1. These two configurations differ due to the placement of the ETM or HTM. When the device configuration has the HTM thin film above the perovskite layer, the architecture is an n-i-p. Conversely, a configuration with the ETM thin film above the perovskite layer is called a p-i-n architecture [5]. Mesoscopic devices usually incorporate porous $\mathrm{TiO}_{2}$ nanoparticles or $\mathrm{ZnO}$ as an active scaffold material and $\mathrm{Al}_{2} \mathrm{O}_{3}$ or $\mathrm{ZrO}_{2}$ as passive scaffolds [6].

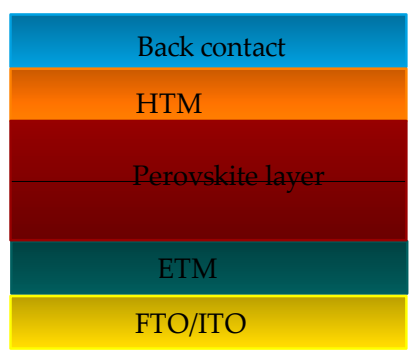

(a)

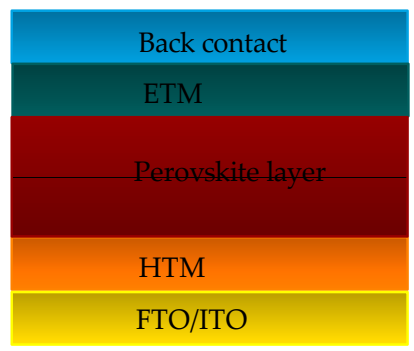

(c)

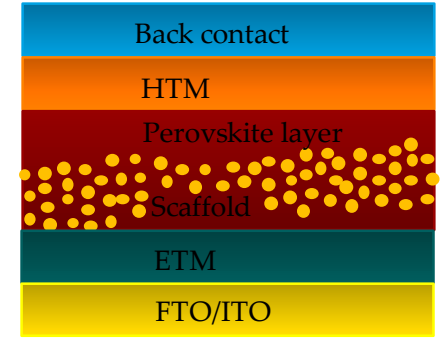

(b)

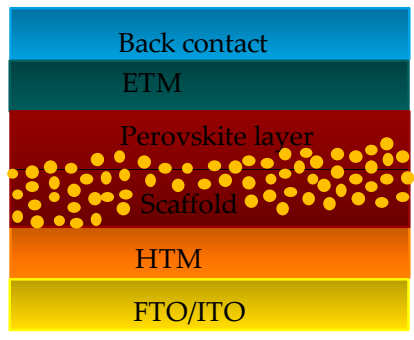

(d)

Figure 1. Perovskite solar cell (PSC) device architectures: (a) planar n-i-p device; (b) mesoscopic n-i-p device; (c) planar p-i-n device; and (d) mesoscopic p-i-n device.

The most commonly studied perovskite materials are hybrid halide perovskites with a formula $\mathrm{ABX}_{3}$, where $\mathrm{A}$ is a monovalent cation such as methylammonium $\left(\mathrm{MA}^{+}\right)$, formamidium $\left(\mathrm{FA}^{+}\right)$; $\mathrm{B}$ is a divalent metal cation such as $\mathrm{Pb}^{2+}$; and $\mathrm{X}$ is a halide such as $\mathrm{Cl}^{-}, \mathrm{I}^{-}$, or $\mathrm{Br}^{-}$. The structure of an ideal perovskite can be described as cubic with $B$ atoms in the center surrounded by an octahedron of anions. The A cations are at the interstices, surrounded by eight octahedra in the cuboctahedral gap, forming a three-dimensional (3D) network [7]. Organic-inorganic hybrid perovskites such as $\mathrm{MAPbI}_{3}$ and $\mathrm{FAPbI}_{3}$ are the most commonly used perovskites in solar cells.

The degradation of PSCs from exposure to moisture, UV radiation, heat, and oxygen as well as toxicity concerns are some of the challenges hindering the commercialization prospects of PSCs. The use of lead in PSCs is of great concern since lead is very toxic, thus any encapsulation failures or leakages would result in detrimental effects [8]. Lead is a renowned toxic heavy metal that bio-accumulates in living organisms. It is carcinogenic, with children being more vulnerable to exposure than adults due to a high frequency of pica, as well as higher intestinal and retention rates $[9,10]$. Exposure to even minimal amounts of lead may result in mental retardation in children, developmental delay, fatal infant encephalopathy, congenital paralysis, acute or chronic damage to the nervous system, epileptics, or kidney, liver and gastrointestinal damage [11,12].

With the photovoltaic community aware of the dangers associated with the use of lead in PSCs $[13,14]$, research has been focused on replacing lead in perovskite materials with other non-toxic metals such as bismuth, germanium, and antimony $[15,16]$. This review paper is focused on presenting the structural, optical, and stability properties of halide double perovskites and the research progress attained so far towards producing lead-free PSCs. 


\section{Heterovalent Substitution}

Heterovalent substitution is an effective approach that has been adopted and led to significant progress in the quest to produce lead-free halide perovskites. The first approach involves replacing the $\mathrm{Pb}^{2+}$ cation with a trivalent cation such as $\mathrm{Sb}^{3+}$ or $\mathrm{Bi}^{3+}$, resulting in a vacancy ordered $\mathrm{A}_{3}{ }^{+} \mathrm{B}_{2}{ }^{3+} \mathrm{X}_{9}{ }^{-}$ perovskite, where $\mathrm{A}$ is a cation such as $\mathrm{Cs}^{+} ; \mathrm{B}$ is a cation such as $\mathrm{Sb}^{3+}$ or $\mathrm{Bi}^{3+}$; and $\mathrm{X}$ is a halide such as $\mathrm{Br}^{-}$[17]. Park et al. [18] reported a power conversion efficiency (PCE) of about $1 \%$ obtained with a PSC employing a hexagonal $\mathrm{Cs}_{3} \mathrm{Bi}_{2} \mathrm{I}_{9}$ perovskite belonging to the $P 6_{3} / m m c$ space group as a light absorber. Zhang et al. [19] replaced the $\mathrm{Cs}^{+}$with $\mathrm{MA}^{+}$to form a hybrid $\left(\mathrm{CH}_{3} \mathrm{NH}_{3}\right)_{3} \mathrm{Bi}_{2} \mathrm{I}_{9}$ perovskite which exhibited a PCE of $1.64 \%$ when used as a light harvester in PSCs. Unfortunately, the $\mathrm{A}_{3} \mathrm{~B}_{2} \mathrm{X}_{9}$ perovskites have been reported to exhibit low structural dimensionality, which results in large bandgaps $(>2 \mathrm{eV})$ as well as poor photovoltaic performances [20]. Hence, the use of $A_{3} B_{2} X_{9}$ perovskites to replace lead halide perovskite light absorbers is not viable due to the issues raised above.

The second approach involves the replacement of lead with two cations, (1) a monovalent metal cation and (2) a trivalent metal cation, to give an average of +2 valence state, which the same as that of $\mathrm{Pb}^{2+}$ in hybrid lead halide perovskites. The halide double perovskites can be described by the formula $\mathrm{A}_{2} \mathrm{~B}^{\prime} B^{\prime \prime} \mathrm{X}_{6}$, with $\mathrm{A}$ being a monovalent cation such $\mathrm{Cs}^{+}$or $\mathrm{MA}^{+}, \mathrm{B}^{\prime}$ being a trivalent metal cation such $\mathrm{Bi}^{3+}$ or $\mathrm{Sb}^{3+}, B^{\prime \prime}$ being a monovalent metal such $\mathrm{Cu}^{+}, \mathrm{Ag}^{+}, \mathrm{or} \mathrm{Na}^{+}$; and $\mathrm{X}$ being a halide such as $\mathrm{Cl}^{-}, \mathrm{Br}^{-}$, or $\mathrm{I}^{-}$[21]. Most of the investigated halide double perovskites have $\mathrm{Sb}^{3+}$ and $\mathrm{Bi}^{3+}$ as the replacement for $\mathrm{Pb}^{2+}[20,22,23] . \mathrm{Bi}^{3+}$ and $\mathrm{Pb}^{2+}$ are isoelectronic while $\mathrm{Sb}^{3+}$ is isoelectronic with $\mathrm{Sn}^{2+}$ which is another ideal ion to replace $\mathrm{Pb}^{2+}$. Therefore, replacing $\mathrm{Pb}^{2+}$ with $\mathrm{Sb}^{3+}$ and $\mathrm{Bi}^{3+}$ would be ideal as it is believed that the excellent optoelectronic properties of hybrid lead halide perovskites are due to the electronic configuration of $\mathrm{Pb}^{2+}\left(6 \mathrm{~s}^{2} \mathrm{p}^{0}\right)[24,25]$.

Two empirical quantities, the Goldschmidt tolerance factor $(t)$ and the octahedral factor $(\mu)$, can be used to predict the crystallographic stability of $\mathrm{A}_{2} \mathrm{~B}^{\prime} B^{\prime \prime} \mathrm{X}_{6}$ perovskites. The formation of halide perovskites generally occurs with a Goldschmidt tolerance factor range of $0.81 \leq \mathrm{t} \leq 1.0$ and an octahedral factor range of $0.44 \leq \mu \leq 0.9$ [26]. The $t_{\text {eff }}$ and $\mu_{\text {eff }}$ can be defined as given in Equations (1) and (2), respectively.

$$
\begin{gathered}
t_{\text {eff }}=\left(R_{A}+R_{X}\right) / \sqrt{ } 2\left[\left(R_{B^{\prime}}+R_{B^{\prime \prime}}\right) / 2+R_{X}\right] \\
\mu_{\text {eff }}=\left(R_{B^{\prime}}+R_{B^{\prime \prime}}\right) / 2 R_{X}
\end{gathered}
$$

Here, $R_{A}, R_{B}, R_{B^{\prime \prime}}$, and $R_{X}$ are the Shannon ionic radii of $A, B^{\prime}, B^{\prime \prime}$, and $X$, respectively [27]. When $t$ or $\mu$ lies within the range, it does not necessarily mean that the required perovskite will form or that the perovskite is stable [28]. These two empirical quantities have been used for the screening and discovery of new halide perovskites. Besides $\mathrm{Sb}$ and $\mathrm{Bi}$, other trivalent cations can be investigated as potential replacements of $\mathrm{Pb}^{2+}$ such as lanthanides, which are thought to have interesting optoelectronic properties [29]. Lanthanide-based halide double perovskites have been synthesized before [30], although to date there has been no report on their optoelectronic and photovoltaic properties. Volonakis et al. [31] stated that obtaining density function theory (DFT) predictions of the optoelectronic properties of transition metals, actinides, and lanthanide double perovskites is challenging. Perhaps the optoelectronic and photovoltaic properties of these lanthanide-based halide double perovskites can be assessed from experimental analysis rather than from theoretical calculations.

Noble metals $\mathrm{Cu}^{+}, \mathrm{Ag}^{+}$, and $\mathrm{Au}^{+}$are normally used as the $B^{\prime \prime}$ monovalent cation since they possess good optoelectronic properties. $\mathrm{Na}^{+}(116 \mathrm{pm})$ can also be used as a $B^{\prime \prime}$ monovalent because its crystal radius is comparable to that of $\mathrm{Ag}^{+}$(129 pm) [32]. Compared to $\mathrm{Cu}$ and $\mathrm{Ag}$, $\mathrm{Au}$ is expensive, making it unsustainable for use in these perovskites. Theoretical calculations for $\mathrm{A}_{2} \mathrm{~B}^{\prime} \operatorname{In} \mathrm{X}_{6}(\mathrm{~A}=\mathrm{Rb}$, $\mathrm{Cs} ; \mathrm{B}^{\prime}=\mathrm{Ag}, \mathrm{Cu}$, and $\mathrm{X}=\mathrm{Cl}, \mathrm{Br}$ ) bandgaps yielded direct bandgaps in the range of 1.36-1.50 eV [33]. Although these bandgaps are close to the optimal bandgap of $1.34 \mathrm{eV}$ for application in single junction solar cells, the synthesis of the copper-based double perovskite is not viable because $\mathrm{Cu}$ crystallizes in a $\mathrm{CuX}_{4}$ coordinate instead of a $\mathrm{CuX}_{6}$ coordinate, which is present in double perovskites as discussed 
below. $\mathrm{In}^{+}$can also be used as a $\mathrm{B}^{\prime}$ cation; however, it quickly oxidizes to $\mathrm{In}^{3+}$, thereby disrupting the perovskite structure. The next section gives a detailed literature review on the structure of $A_{2} B^{\prime} B^{\prime \prime} X_{6}$ double perovskites.

\section{Structure}

The most investigated halide double perovskites have been reported to possess a cubic face-centered structure belonging to the space group $\mathrm{Fm}-3 \mathrm{~m}$ and with a lattice parameter ranging from approximately 10-12 $\AA$ [34-36]. The structure is similar to the $\mathrm{ABX}_{3}$ perovskite structure, composed of a 3D network of corner connected octahedra, with $\mathrm{Cs}^{+}$ions in the center of the cuboctahedron interstices. Unlike the hybrid halide perovskites where the perovskite structure is obtained by just $\mathrm{B}^{2+}$ centered octahedron [7], the halide double perovskite structure is built of alternating $B^{\prime}$ and $B^{\prime \prime}$ centered octahedrons of $\mathrm{B}^{\prime} \mathrm{X}_{6}$ and $\mathrm{B}^{\prime} \mathrm{X}_{6}$ in a $3 \mathrm{D}$ framework known as rock salt ordering. The conventional ideal structures of the hybrid halide perovskites and halide double perovskites are given below in Figure 2 . The structure of halide double perovskites is similar to that of oxide double perovskites such as $\mathrm{Sr}_{2} \mathrm{FeMoO}_{6}$, which are known to possess interesting properties such as ferroelectricity, ferromagnetism, and superconductivity [37].

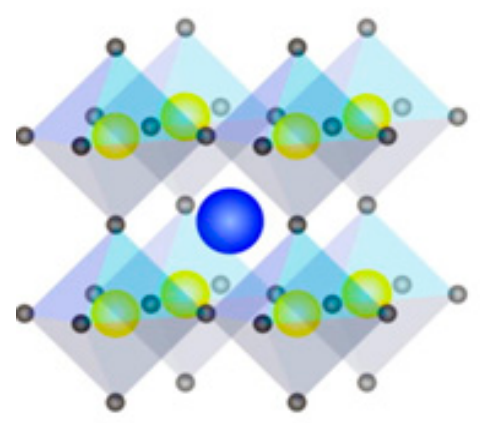

(a)

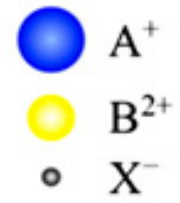

Figure 2. (a) Structure of ideal $A B X_{3}$ halide perovskites. (b) Structure of ideal $A_{2} B^{\prime} B^{\prime \prime} X_{6}$ halide double perovskites. Reproduced with permission from Reference [21]. Elsevier, 2018.

Wei et al. [38] synthesized a hybrid double perovskite $\left((\mathrm{MA})_{2} \mathrm{KBiCl}_{6}\right)$ which crystallized in a 3D distorted structure belonging to the R3- $m$ space group, as shown in Figure 3, with lattice parameters of $\mathrm{a}=7.84 \AA$ and $\mathrm{c}=20.99 \AA$. The distortion of the $(\mathrm{MA})_{2} \mathrm{KBiCl}_{6}$ structure from the cubic structure which is exhibited by most halide double perovskites is due to the differences in size between the $\mathrm{K}^{+}$ and $\mathrm{Bi}^{3+}$ ionic radii. The $\mathrm{Bi}-\mathrm{Cl}$ bond length $(2.68 \AA)$ was shorter than that of $\mathrm{K}-\mathrm{Cl}(3.05 \AA)$. The $\mathrm{MA}^{+}$ alternate along the $\mathrm{c}$ direction with the symmetry equivalent $\mathrm{MA}^{+}$adopting opposite orientations and $\mathrm{C}-\mathrm{N}$ bond lengths of $1.35 \AA$. The bond length of $\mathrm{N}-\mathrm{Cl}$ is $3.41 \AA$, which is shorter than the $\mathrm{C}-\mathrm{Cl}$ bond length of $3.85 \AA$; this implies hydrogen bonding. The degree of tilting in the distorted structure is less than in the orthorhombic phase of the $\mathrm{MAPbCl}_{3}$ hybrid perovskite. The experimental X-ray diffraction (XRD) studies were in agreement with the DFT (density function theory) geometry optimization in $R 3-m$ results with lattice parameters of $\mathrm{a}=7.82 \AA$ and $\mathrm{c}=20.99 \AA .(\mathrm{MA})_{2} \mathrm{KBiCl}_{6}$ exhibited a wide and indirect bandgap $(3.0 \mathrm{eV})$ similar to the bandgap of $\mathrm{MAPbCl}_{3}$, rendering it unsuitable for single junction solar cell application. 


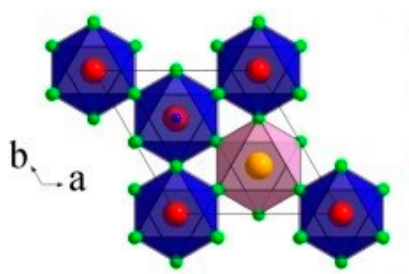

(a)

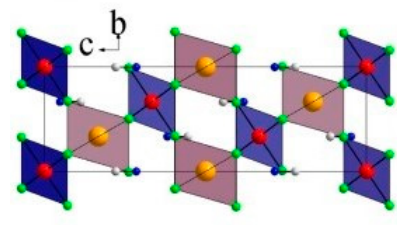

(b)

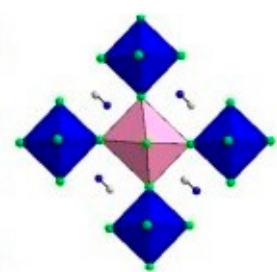

(c)

Figure 3. Crystal structure of $(\mathrm{MA})_{2} \mathrm{KBiCl}_{6}$, obtained from single crystal X-ray diffraction, viewed along (a) the $\mathrm{c}$ axis, (b) the a axis, and (c) tilted to show the MA location. Red: Bi, brown: $\mathrm{K}$, green: $\mathrm{Cl}$, white: $\mathrm{C}$, blue: $\mathrm{N}$. $\mathrm{BiCl}_{6}$ and $\mathrm{KCl}_{6}$ octahedra are shown in blue and purple, respectively. Reproduced with permission from Reference [38]. Royal Society of Chemistry, 2016.

However, Wei et al. [39] also reported another hybrid double perovskite ((MA) $\left.{ }_{2} \mathrm{AgBiBr}_{6}\right)$ that crystallized into an ordered 3D cubic structure belonging to the space group $\mathrm{Fm}$-3m and with a lattice parameter of $11.64 \AA$. Surprisingly, the $\mathrm{MA}^{+}$orientation was disordered in the cavity, as observed in the $(\mathrm{MA})_{2} \mathrm{KBiCl}_{6}$ double perovskite. The $\mathrm{Ag}-\mathrm{Br}$ bond length was $2.95 \AA$, while that of $\mathrm{Bi}-\mathrm{Br}$ was $2.87 \AA$. To the best of our knowledge, the photovoltaic performance of the reported (MA) ${ }_{2} \mathrm{AgBiBr}_{6}$ double perovskite has not been reported. This might be due to its wide bandgap, which makes it unsuitable to replace hybrid lead halide perovskites.

Moreover, Deng et al. [40] reported a (MA) $)_{2} \mathrm{TlBiBr}_{6}$ that is isoelectronic with $\mathrm{MAPbBr}_{3}$ and that also crystallized into a 3D cubic structure belonging to the space group Fm-3m with a lattice parameter of $11.76 \AA$. The $(\mathrm{MA})_{2} \mathrm{TlBiBr}_{6}$ double perovskite had a direct bandgap of $2.16 \mathrm{eV}$. However, thallium is more toxic than lead [41], thus rendering $(\mathrm{MA})_{2} \operatorname{TlBiBr}_{6}$ unsuitable to replace hybrid halide perovskites. Volonakis et al. [31] synthesized another lead-free double perovskite of the formula $\mathrm{Cs}_{2} \mathrm{InAgCl}_{6}$. The density functional theory/local density approximation (DFT/LDA) calculations predicted that this lead-free perovskite $\mathrm{Cs}_{2} \mathrm{InAgCl}_{6}$ would crystallize into an ordered cubic structure. Experimental findings by Volonakis et al. were in close agreement with the DFT/LDA approximation, which reported the presence of a 3D cubic structure belonging to the space group $F m-3 m$ and with a lattice parameter of $10.47 \AA$. This was further cemented by the XRD analysis shown here in Figure 4 . Even though the $\mathrm{Cs}_{2} \mathrm{InAgCl}$ double perovskite crystallized into a 3D structure, it exhibited a direct wide bandgap of $3.3 \mathrm{eV}$, which makes it unsuitable for single junction solar cell application.

Hybrid lead halide perovskites have shown remarkable photovoltaic performance when used in PSCs. Various structural dimensions, such as two-dimensional (2D) and 3D, of these hybrid lead halide perovskites have been explored as light absorbers in PSCs. The 3D structures of these perovskites have shown a better photovoltaic performance, which is ideal for single junction solar cell applications [42,43]. Most studied halide double perovskites exhibited 3D structures; however, their bandgaps were very wide, which means that the photovoltaic performance of these perovskites is not only dependent on structural dimensionality. Xiao et al. [43] introduced the concept of electronic dimensionality to help explain why the 3D halide double perovskites do not exhibit ideal photovoltaic performance as their 3D hybrid halide perovskites counterparts do. Electronic dimensionality is the connectivity of lower conduction band and upper valence band atomic orbitals. High electronic dimensionality is needed for perovskites to exhibit good photovoltaic performance. Even though the halide double perovskites crystallize into 3D structural dimension, they might exhibit low electronic dimensionality, rendering them unsuitable for single junction solar cell application. 


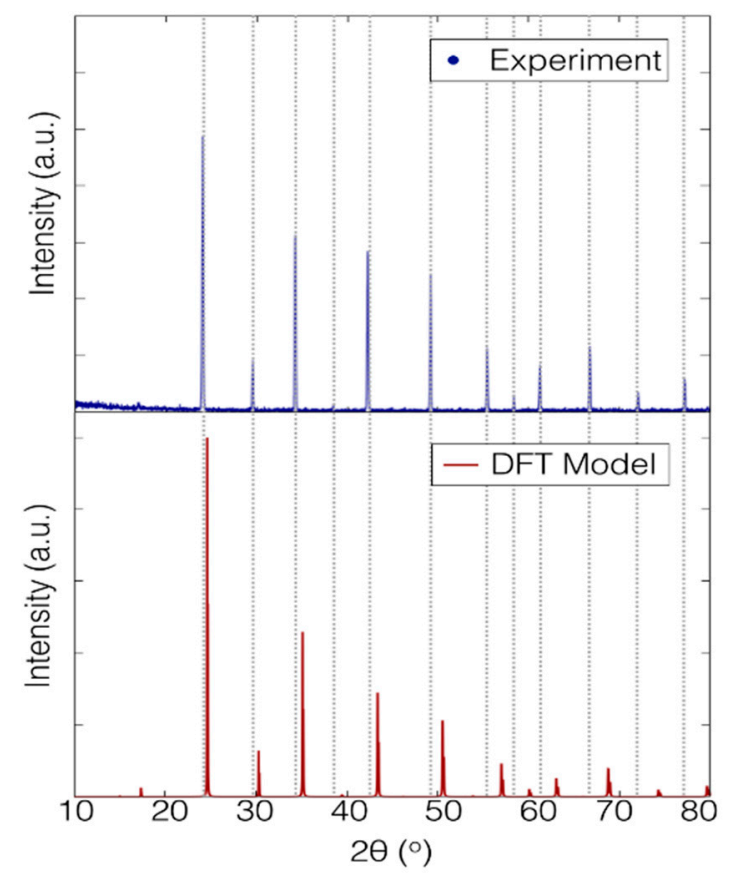

Figure 4. Measured powder XRD pattern for $\mathrm{Cs}_{2} \mathrm{InAgCl}_{6}$ (top), and the XRD pattern calculated from the atomistic model optimized using density functional theory/local density approximation (DFT/LDA) (bottom). Reproduced with permission from Reference [31]. American Chemical Society, 2017.

\section{Optical}

Optical properties of halide double perovskites are determined by investigating their visible light-harvesting capacity. This is normally done through the calculation of absorption coefficients as well as the determination of their energy bandgaps. Since the absorption threshold is inversely proportional to the energy bandgap, perovskites with higher bandgaps should have narrow absorption in the visible range. Lead-free halide double perovskites exhibit both direct and indirect bandgaps. UV-Vis diffuse spectra recorded by McClure et al. [36] showed that both $\mathrm{Cs}_{2} \mathrm{AgBiCl}_{6}$ and $\mathrm{Cs}_{2} \mathrm{AgBiBr}_{6}$ exhibited indirect bandgaps. The calculation of optical bandgaps for the synthesized perovskites using the Kubelka-Munk equation yielded bandgaps of $2.19 \mathrm{eV}$ and $2.77 \mathrm{eV}$ for $\mathrm{Cs}_{2} \mathrm{AgBiCl}_{6}$ and $\mathrm{Cs}_{2} \mathrm{AgBiBr}_{6}$, respectively. Bandgaps for the hybrid lead perovskites were $2.26 \mathrm{eV}$ and $3 \mathrm{eV}$ for $\mathrm{MAPbBr}_{3}$ and $\mathrm{MAPbCl}_{3}$ respectively. In this work, it was noted that despite observable similarities between the $\mathrm{Cs}_{2} \mathrm{AgBiX}_{6}$ perovskites and the $\mathrm{MAPbX}_{3}$, mild absorption onset was observed in the double perovskites as compared to $\mathrm{MAPbBr}_{3}$ and $\mathrm{MAPbCl}_{3}$. This is clearly illustrated in Figure 5.

The late absorption onset was attributed to the indirect bandgap in double perovskites. The indirect bandgaps of $\mathrm{Cs}_{2} \mathrm{AgBiX} \mathrm{X}_{6}$ perovskites are not ideal for thin film photovoltaic applications; however, recent developments have shown that bandgaps can be transformed from indirect to direct. Since bandgaps are dependent on the lattice parameters of the developed perovskites they can therefore be manipulated from indirect to direct by varying operational temperature, pressure, and doping with another element.

Other researchers have nonetheless fabricated halide double perovskites with direct bandgaps. Volonakis and associates [31] synthesized $\mathrm{Cs}_{2} \mathrm{InAgCl}_{6}$ with a direct bandgap of $3.3 \mathrm{eV}$. The onset of absorption for this perovskite was observed at $380 \mathrm{~nm}$ with a second absorption at $585 \mathrm{~nm}$. Comparison of the optical absorption spectra for $\mathrm{Cs}_{2} \mathrm{InAgCl}_{6}$ and $\mathrm{Cs}_{2} \mathrm{InAgBr}_{6}$ with those of $\mathrm{Si}, \mathrm{GaAs}$, and $\mathrm{MAPbI}_{3}$ shows that despite having a direct bandgap, the absorption coefficient for $\mathrm{Cs}_{2} \mathrm{InAgCl}_{6}$ is much smaller than those of the other perovskites throughout the visible spectrum. A comparable absorption coefficient for halide double perovskites can only be obtained if the synthesis of an ideal crystal of $\mathrm{Cs}_{2} \operatorname{InAgBr}_{6}$ was successful. Investigation into the optical characteristics of the sodium-based 
perovskites $\mathrm{Cs}_{2} \mathrm{NaBX}_{6}$ (where $\mathrm{B}=\mathrm{Sb}, \mathrm{Bi} ; \mathrm{X}=\mathrm{Cl}, \mathrm{Br}$, I) yielded iodide perovskites $\mathrm{Cs}_{2} \mathrm{NaSbI}_{6}$ and $\mathrm{Cs}_{2} \mathrm{NaBiI}_{6}$, with optimal bandgaps of $2.03 \mathrm{eV}$ and $2.43 \mathrm{eV}$, respectively. Thus, they can potentially be used in solar cell applications. As illustrated in Figure 6, $\mathrm{Cs}_{2} \mathrm{NaSbI}_{6}, \mathrm{Cs}_{2} \mathrm{NaBiI}_{6}$, and $\mathrm{Cs}_{2} \mathrm{NaSbBr}_{6}$ exhibited efficient absorption coefficients in the visible range. This was attributed to the fact that transitions in these compounds are $p$-p valence to conduction band transitions [44]. To date, bandgaps of all synthesized double halide perovskites are still too large for single junction solar cell application.

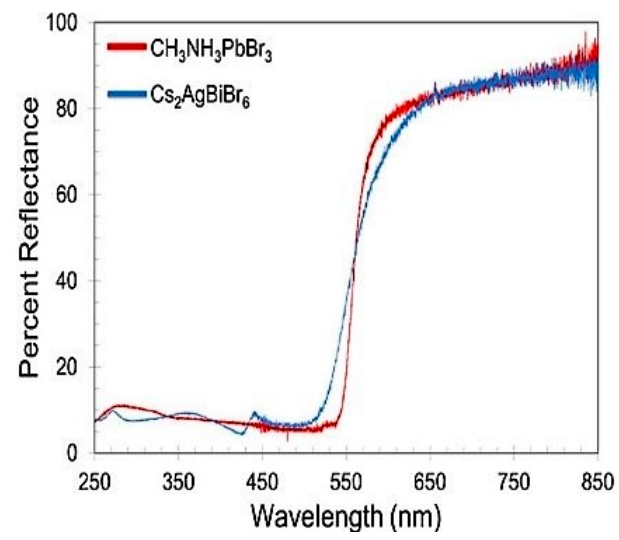

(a)

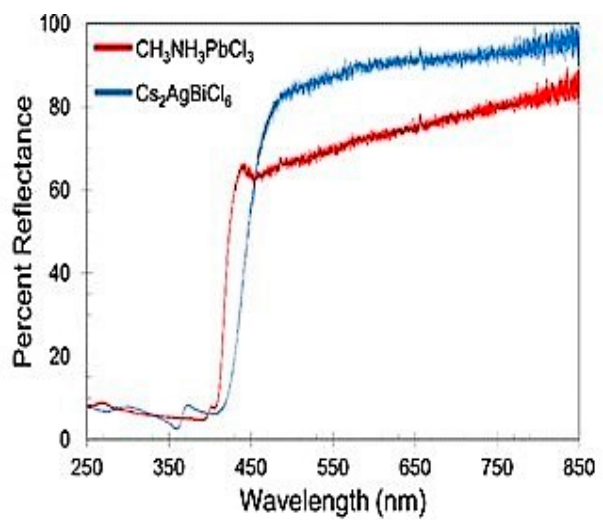

(b)

Figure 5. (a) UV-Vis diffuse reflectance spectra for $\mathrm{Cs}_{2} \mathrm{AgBiBr}_{6}$ and $\mathrm{MAPbBr}_{3}$, (b) UV-Vis diffuse reflectance spectra for $\mathrm{Cs}_{2} \mathrm{AgBiCl}_{6}$ and $\mathrm{MAPbBr}_{3}$. Reproduced with permission from Reference [36]. American Chemical Society, 2016.

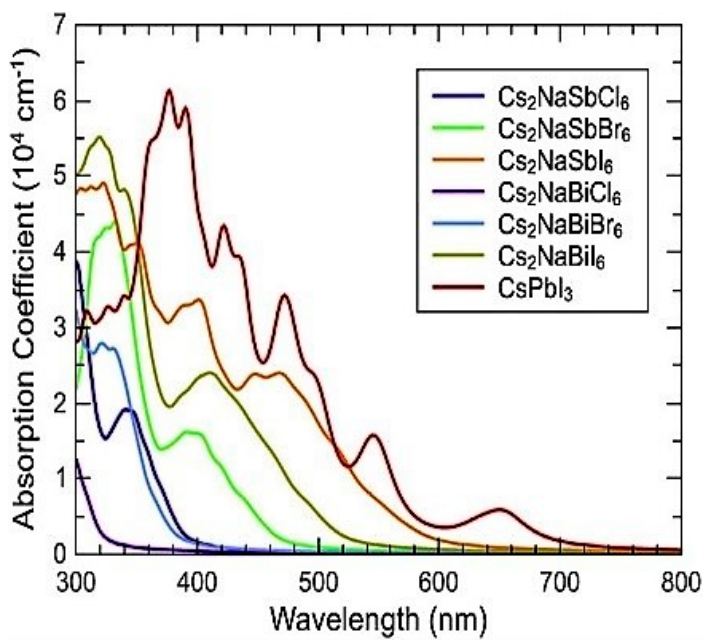

Figure 6. Optical absorption spectra for the $\mathrm{Cs}_{2} \mathrm{NaBX}_{6}$ double perovskites $(\mathrm{B}=\mathrm{Bi}, \mathrm{Sb} ; \mathrm{X}=\mathrm{Cl}, \mathrm{Br}, \mathrm{I})$. Reproduced with permission from Reference [44]. Elsevier, 2018.

Another class of halide double perovskite which could possess bandgaps that are useful for photovoltaic applications is the class of hybrid halide double perovskites. Even though organic compounds are known to be susceptible to thermal instability, hybrid halide double perovskites have otherwise shown excellent thermal stability. Wei et al. [39] fabricated one such hybrid perovskite, $(\mathrm{MA})_{2} \mathrm{AgBiBr}_{6}$, which possessed a smaller bandgap whilst being thermally stable up to $400{ }^{\circ} \mathrm{C}$. Optical bandgaps from absorption and diffuse reflectance spectra yielded an indirect bandgap of $2.02 \mathrm{eV}$, which is comparable to its cesium-based analogue reported by Volonakis et al. [34]. Wei and co-workers reported that the bandgap of $(\mathrm{MA})_{2} \mathrm{AgBiBr}_{6}$ is narrow enough to exhibit semiconducting properties; however, its electronic conductivity is deemed to be lower than its ionic conductivity at $4.8 \times 10^{8} \Omega \cdot \mathrm{cm}$. 
Due to the wide indirect bandgap of $(\mathrm{MA})_{2} \mathrm{AgBiBr}_{6}$, a low PCE should be expected. The wide bandgaps minimize the potential for any photovoltaic application. In a similar manner, Wei et al. [38] also synthesized (MA) ${ }_{2} \mathrm{KBiBr}_{6}$, which was reported to have similarities to $\mathrm{MAPbCl}_{3}$. UV-Vis measurements obtained two values of 3.04 and $3.37 \mathrm{eV}$ as the optical bandgaps. The theoretical band structure of (MA) ${ }_{2} \mathrm{KBiBr}_{6}$ using DFT recognized an indirect bandgap of $3.08 \mathrm{eV}$, which is consistent with the experimental data. In this work, Wei and colleagues revealed that the main contributors to the electronic density of states near the bandgap edge were $\mathrm{Bi}$ and $\mathrm{Cl}$. The valence band was composed of $\mathrm{Bi}-6 \mathrm{~s}$ and $\mathrm{Cl}-3 \mathrm{p}$ antibonding, whereas the conduction band was composed of $\mathrm{Bi}-6 \mathrm{p}, \mathrm{Cl}-3 \mathrm{p}$, and Cl-3s. The optical bandgaps for both hybrid halide double perovskites are unsuitable for single junction solar cell application.

\section{Stability}

\subsection{Influence of Light and Moisture on Stability}

The most significant drawback associated with perovskite materials and solar cells has been their poor stability when exposed to heat, oxygen, humidity, and illumination [45]. The best-performing hybrid lead halide perovskite, $\mathrm{MAPbI}_{3}$, undergoes severe degradation when exposed to weather elements. It has been reported that $\mathrm{MAPbI}_{3}$ changes phase at the onset of degradation, culminating in accelerated decomposition to $\mathrm{PbI}_{2}$ [46]. In comparison, halide double perovskites have shown remarkable stability in various weather elements such that they might be the answer to the stability issues in perovskite solar cells.

McClure et al. [36] probed the stability of $\mathrm{Cs}_{2} \mathrm{AgBiCl}_{6}$ and $\mathrm{Cs}_{2} \mathrm{AgBiBr}_{6}$ in ambient atmosphere. When the samples were placed in darkness for a period of two weeks, no changes were observed on the exposed surfaces. However, darkening was observed when the samples were exposed to visible light. Subsequent reflectance measurements proved that the degradation of the halide double perovskite occurred, as shown in Figures 7 and 8 below.

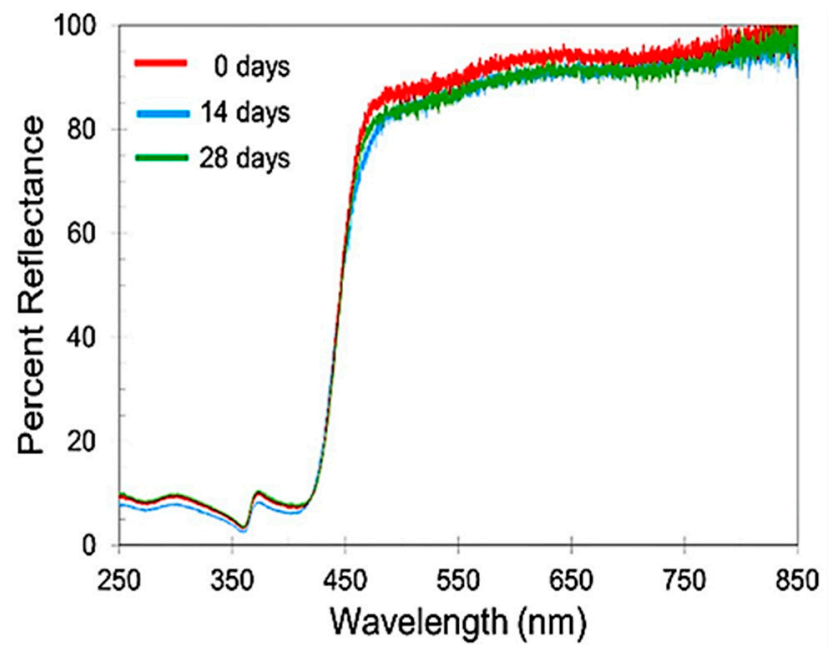

Figure 7. UV-Vis diffuse reflectance spectra showing the light stability of $\mathrm{CsAgBiCl}_{6}$ after two and four weeks of light exposure. Reproduced with permission from Reference [36]. American Chemical Society, 2016.

As clearly indicated in Figure $7, \mathrm{Cs}_{2} \mathrm{AgBiCl}_{6}$ undergoes minimum degradation during a month's exposure to light, which is reflected by a minimal decrease in total reflectance. In contrast, $\mathrm{Cs}_{2} \mathrm{AgBiBr}_{6}$ undergoes severe degradation characterized by a sharp decline in total reflectance, as shown in Figure 8. 


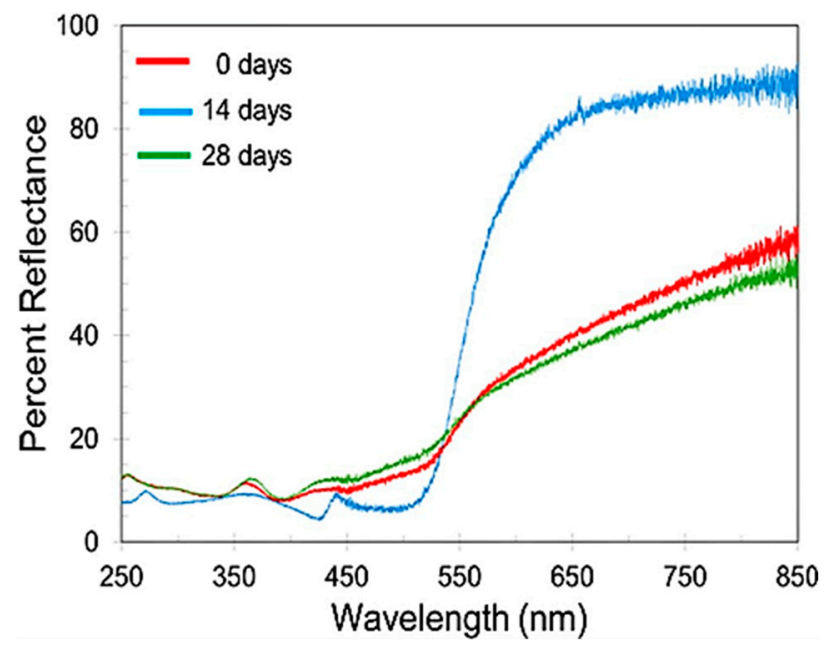

Figure 8. UV-Vis diffuse reflectance spectra showing the light stability of $\mathrm{CsAgBiBr}_{6}$ after two and four weeks of light exposure. Reproduced with permission from Reference [36]. American Chemical Society, 2016.

The instability of bromine-based double perovskites was also observed by Volonakis et al. [31]. Their synthesis of double halide $\mathrm{Cs}_{2} \operatorname{InAgX} X_{6}$ yielded a stable $\mathrm{Cs}_{2} \mathrm{InAgCl}_{6}$ with no observable structural decomposition when exposed to ambient conditions for more than three months. The fabrication of the bromide perovskite was, however, not successful at all. This anomaly was attributed to the fact that the $\mathrm{In}^{3+}$ radii is too small to properly coordinate $6 \mathrm{Br}^{-}$anions. A pre-synthesis assessment of $\mathrm{Cs}_{2} \mathrm{AgBiBr}_{6}$ stability using the Goldschmidt empirical criteria yields tolerance and octahedral factors of $\mathrm{t}=0.83$ and $\mu=0.584$, respectively. This indicates that a structurally stable $\mathrm{Cs}_{2} \mathrm{AgBiBr}_{6}$ can be feasibly fabricated. Comparison of the radii between $\mathrm{Bi}^{3+}$ and the $\mathrm{Br}^{-}$suggests that the bismuth cation is capable of adequately coordinating six bromine anions. Therefore, more research work is required to determine why $\mathrm{Cs}_{2} \mathrm{AgBiBr}_{6}$ is unstable. Consequently, at the present moment effective protection against the effects of light can only be minimized by encapsulation.

\subsection{Influence of Temperature on Stability}

Solar panels require thermal stability since they function under elevated temperatures. As per the international standard, panels must withstand temperatures reaching up to $85^{\circ} \mathrm{C}$, corresponding to $0.093 \mathrm{eV}$. Hence, in order to withstand these temperatures, the energy of formation for lead-free double halide perovskites must be higher than $0.093 \mathrm{eV}$. Pre-synthesis assessment of the thermodynamic stability of halide double perovskites is done through the calculation of the energies of formation based on Equation (3).

$$
2 \mathrm{Cs}_{2} \mathrm{~B}^{\prime} B^{\prime \prime} \mathrm{X}_{6} \leftrightarrow \mathrm{Cs}_{2} \mathrm{~B}^{\prime} \mathrm{X}_{9}+2 B^{\prime \prime} \mathrm{X}+\mathrm{Cs} \mathrm{X},
$$

where $\Delta \mathrm{H}=2 \mathrm{H}\left(\mathrm{Cs}_{2} \mathrm{~B}^{\prime} B^{\prime \prime} \mathrm{X}_{6}\right)-\mathrm{H}\left(\mathrm{Cs}_{2} \mathrm{~B}^{\prime} \mathrm{X}_{9}\right)+2 \mathrm{H}\left(B^{\prime \prime} X\right)+\mathrm{H}(\mathrm{Cs} X)$.

Table 1 depicts the calculated formation energies for some common double halide perovskites. A negative enthalpy of formation indicates that the perovskite is presumed to be thermodynamically stable, whereas a positive $\Delta \mathrm{H}$ implies that the perovskite is spontaneous and unstable. From Table 1 , it is clear that the sodium-based chlorides as well as $\mathrm{Cs}_{2} \mathrm{AgBiI}_{6}$ have an endothermic phase decomposition; thus, they can be deemed to be thermodynamically stable. In order to understand the effects of temperature on the double halide perovskites, an experimental analysis was conducted in which the synthesized perovskites were exerted to a wide range of temperatures. One such study on the thermal stability of $\mathrm{Cs}_{2} \mathrm{AgBiBr}_{6}$ was conducted by Dong et al. [23]. Results from his work showed that $\mathrm{Cs}_{2} \mathrm{AgBiBr}_{6}$ undergoes minimal thermal expansion as compared to other perovskites. Since the thermal stability of the perovskite depends on the crystal structure and bond strength, measurements 
on the expansion of the unit cell were taken. For the temperature range from 120 to $360{ }^{\circ} \mathrm{C}$, the cell volume and axis length increased by $0.67 \%$ and $2.01 \%$, respectively.

Table 1. Calculated values of enthalpy of formation for various double halide perovskites.

\begin{tabular}{ccc}
\hline Compounds & $\Delta \mathbf{H} / \mathbf{e V}$ & Reference \\
\hline $\mathrm{Cs}_{2} \mathrm{AgBiCl}_{6}$ & +0.57 & {$[47]$} \\
$\mathrm{Cs}_{2} \mathrm{AgBiBr}_{6}$ & +0.38 & {$[47]$} \\
$\mathrm{Cs}_{2} \mathrm{AgBil}_{6}$ & -0.41 & {$[47]$} \\
$\mathrm{Cs}_{2} \mathrm{InBiCl}_{6}$ & +0.01 & {$[47]$} \\
$\mathrm{Cs}_{2} \mathrm{InBiBr}_{6}$ & -0.04 & {$[47]$} \\
$\mathrm{Cs}_{2} \mathrm{NaSbCl}_{6}$ & -0.19 & {$[44]$} \\
$\mathrm{Cs}_{2} \mathrm{NaBiCl}_{6}$ & -0.43 & {$[44]$} \\
$\mathrm{Cs}_{2} \mathrm{NaSbl}_{6}$ & +0.49 & {$[44]$} \\
$\mathrm{Cs}_{2} \mathrm{NaBil}_{6}$ & +0.40 & {$[44]$} \\
$\mathrm{Cs}_{2} \mathrm{NaBiBr}_{6}$ & +0.01 & {$[44]$} \\
$\mathrm{Cs}_{2} \mathrm{NaSbBr}_{6}$ & +0.11 & {$[44]$} \\
\hline
\end{tabular}

In comparison to other perovskite compounds, the stability of $\mathrm{Cs}_{2} \mathrm{AgBiBr}_{6}$ (shown in Table 2) was attributed to the stronger bonding characteristics and the absence of organic components which impact higher structural stiffness, thus resulting in a low susceptibility to temperature perturbation. Perhaps the most significant development for lead-free halide double perovskites has been the discovery that cesium-based perovskites withstand temperatures up to $300{ }^{\circ} \mathrm{C}$. To the best of our knowledge, no analysis has been performed on halide double perovskites, but results obtained from the investigation of $\mathrm{CsPbI}_{3}$ showed that cesium could be the answer to attaining perovskite stability [48]. This fact bodes well for most halide double perovskites since they contain cesium. Niu et al. [49] produced thermally stable $\mathrm{Cs}_{\mathrm{x}} \mathrm{MA}_{1-\mathrm{x}} \mathrm{PbI}_{3}$ perovskites compared to the best-performing $\mathrm{MAPbI}_{3}$. An analysis of the results from this work showed that these perovskites were only stable for amounts of cesium between 0.09 and 0.20. Any further increase in cesium resulted in a rapid decrease of the thermal stability of the synthesized element. The addition of cesium invigorates the film deposition rate, leading to a decrease in grain size.

Table 2. Experimental values of bulk moduli B, hardness H, Young's moduli E, and linear thermal expansion coefficient $\dot{\alpha}$ for four perovskites.

\begin{tabular}{cccccc}
\hline Perovskite & B(GPA) & H(GPA) & E(GPA) & $\dot{\alpha}$ MK $^{-1}$ & Reference \\
\hline $\mathrm{Cs}_{2} \mathrm{AgBiBr}_{6}$ & 27.3 & 0.67 & 22.6 & 27.8 & {$[23]$} \\
$\mathrm{CsPbBr}_{3}$ & 15.5 & 0.34 & 15.8 & 37.7 & {$[23]$} \\
$\mathrm{MAPbI}_{3}$ & 10.2 & 0.42 & 10.4 & 43.3 & {$[39]$} \\
$(\mathrm{MA})_{2} \mathrm{AgBiBr}_{6}$ & 7.7 & 0.55 & 7.9 & 44 & {$[39]$} \\
\hline
\end{tabular}

Theoretically, plenty of halide double perovskites can be synthesized. However, their weak stability has meant that only a few have been synthesized thus far. In order to produce more stable halide double perovskites, a pre-synthesis assessment of suitable compositions, the properties of the materials to be used, and the limitations to the synthesis procedures should be known. One viable way of determining which compositions of halide double perovskites could be more stable is a strategy where a combination of first principles DFT calculations and machine learning is used to screen for stable perovskite compositions. The machine learning part is used to predict decomposition energies $\Delta \mathrm{H}_{\mathrm{D}}$, which then provides insight and guidance on experimental studies.

Another challenge that is encountered during the fabrication of halide double perovskites is the instability associated with the starting materials. Halide double perovskites can be synthesized via various techniques such as solvent evaporation, the hydrothermal method, solid state sintering, and growth from melt. Chlorides form relatively easily, whereas bromides and iodides are very 
difficult to fabricate. To date, only three iodine-based halide double perovskites have been successfully synthesized via growth from a melt. Synthesis is however reported to be more difficult for hybrid halide double perovskites due to the low decomposition temperatures of the organic starting material. As a result, synthesis techniques involving elevated temperatures have to be avoided, thereby limiting viable synthesis options. Wei et al. [38] synthesized (MA) ${ }_{2} \mathrm{KBiCl}_{6}$ via the hydrothermal method while $\mathrm{Li}$ et al. [50] synthesized (MA) ${ }_{2} \mathrm{AgSbI}_{6}$ via the solid state method in sealed vacuum tube. According to Volokanis et al. [34], the successful synthesis of $\mathrm{Cs}_{2} \mathrm{BiAgCl}_{6}$ can be attributed to the close match in radii between $\mathrm{Na}^{+}(1.02 \mathrm{~A})$ and $\mathrm{Ag}(1.15 \mathrm{~A})$. In their work, they replaced the $\mathrm{NaCl}$ precursor with $\mathrm{AgCl}$ in the preparation of $\mathrm{Cs}_{2} \mathrm{BiNaCl}_{6}$. Hence, it is of particular importance that the most ideal method of synthesis be used to increase the probability of successfully fabricating a particular perovskite compound.

\section{Current Progress of Halide Double Perovskites}

Owing to the difficulties in the formation of high-quality and uniform halide double perovskites and thin films, the testing of the performance of halide double perovskites in photovoltaics has not been extensively reported. To date, only one halide double perovskite has been employed in a planar heterojunction solar cell. Wu et al. [51] reported an PCE of $1.44 \%$ using an $\mathrm{Au} / \mathrm{P} 3 \mathrm{HT} / \mathrm{Cs}_{2} \mathrm{AgBiBr}_{6} / \mathrm{SnO}_{2} / \mathrm{ITO}$ device architecture. The device was fabricated using low-pressure assisted solution processing which involved spin coating, pumping of low pressure, and then thermal annealing under ambient conditions. This process has also been used in the fabrication of some hybrid lead halide-based PSCs. Ning et al. [52] also fabricated a planar heterojunction solar cell that employed $\mathrm{Cs}_{2} \mathrm{AgBiBr}_{6}$ as a light absorber. Instead of using P3HT and $\mathrm{SnO}_{2}$ as the HTM and ETM, respectively, Ning and co-workers employed SpiroMeOTAD and $\mathrm{TiO}_{2}$ as the HTM and ETM, respectively. A PCE of $1 \%$ was reached by an $\mathrm{Au} /$ SpiroMeOTAD $/ \mathrm{Cs}_{2} \mathrm{AgBiBr}_{6} / \mathrm{TiO}_{2} / \mathrm{ITO}$ device architecture. Both device architectures suffered from low efficiencies, which were attributed to the poor charge injection from the light absorber to both HTMs and ETMs. However, they both showed better stability than the hybrid lead halide perovskites. The charge injection issue can be solved by changing the ETM with a more suitable one. It was found that interface modification through passivation or the deposition of polymer on the inorganic ETM improves charge extraction [53]. Therefore, using a modified ETM may help improve the charge injection of these $\mathrm{Cs}_{2} \mathrm{AgBiBr}_{6}$-based heterojunction solar cells. There is also need for device optimization and bandgap engineering to change the indirect bandgap. Moreover, doping with $\mathrm{Sb}$ or $\mathrm{Tl}$ can reduce the bandgap of the $\mathrm{Cs}_{2} \mathrm{AgBiBr}_{6}$ double perovskite for improved efficiencies.

As outlined earlier, recent research has shown that doping these halide double perovskites could alter the type of bandgap produced as well as narrow its width. Slavney et al. [54] reported a Tl-doped $\mathrm{Cs}_{2}\left(\mathrm{Ag}_{1-\mathrm{a}} \mathrm{Bi}_{1-\mathrm{b}}\right) \mathrm{Tl}_{\mathrm{x}} \mathrm{Br}_{6}$ double perovskite with a bandgap reduced by $0.5 \mathrm{eV}$ at $\mathrm{x}=0.075$. However, with thallium being more toxic than lead, it might not be an ideal alternative for doping purposes. Using $\mathrm{Cs}_{2} \mathrm{AgBiBr}_{6}$ as a host, Du et al. [55] investigated band modification with $\mathrm{Sb}^{3+}$ and $\mathrm{In}^{3+}$ on the $\mathrm{Bi}^{3+}$ lattice site. Their work revealed that lattice constants of $\mathrm{Cs}_{2} \mathrm{Ag}\left(\mathrm{Bi}_{1-\mathrm{x}} \mathrm{M}_{\mathrm{x}}\right) \mathrm{Br}_{6}$ (where $\mathrm{M}=$ $\mathrm{Sb}, \mathrm{In}$ ) decrease linearly as $\mathrm{x}$ increases, with In being able to replace $75 \%$ of $\mathrm{Bi}$ while $\mathrm{Sb}$ could only replace $37.5 \%$ of $\mathrm{Bi}$. UV-Vis data from this work showed that the bandgap of $\mathrm{Cs}_{2} \mathrm{Ag}\left(\mathrm{Bi}_{1-\mathrm{x}} \mathrm{In}_{\mathrm{x}}\right) \mathrm{Br}_{6}$ increased from 2.12 to $2.27 \mathrm{eV}$ as $\mathrm{x}$ increased to 0.75 . However, a decrease of $0.26 \mathrm{eV}$ was noted for $\mathrm{Cs}_{2} \mathrm{Ag}\left(\mathrm{Bi}_{1-\mathrm{x}} \mathrm{Sb}_{\mathrm{x}}\right) \mathrm{Br}_{6}$ as $\mathrm{x}$ increased from 0 to 0.375 . The introduction of In led to the downward shifting of the conduction band minimum (CBM) as well as a downward movement of the valence band maximum (VBM) due to the reduction of Bi atoms. Therefore, in order for the bandgap to increase, the downward motion of the VBM should be greater than the downward motion of the CBM. The bandgaps of the doped perovskites remained indirect, which is still a challenge to be solved. Figure 9 shows a schematic of the energy levels of $\mathrm{Cs}_{2} \mathrm{AgBiBr}_{6}$ and $\mathrm{Sb}$-doped $\mathrm{Cs}_{2} \mathrm{AgBiBr}_{6}$ halide double perovskites with various ETMs and HTMs. 


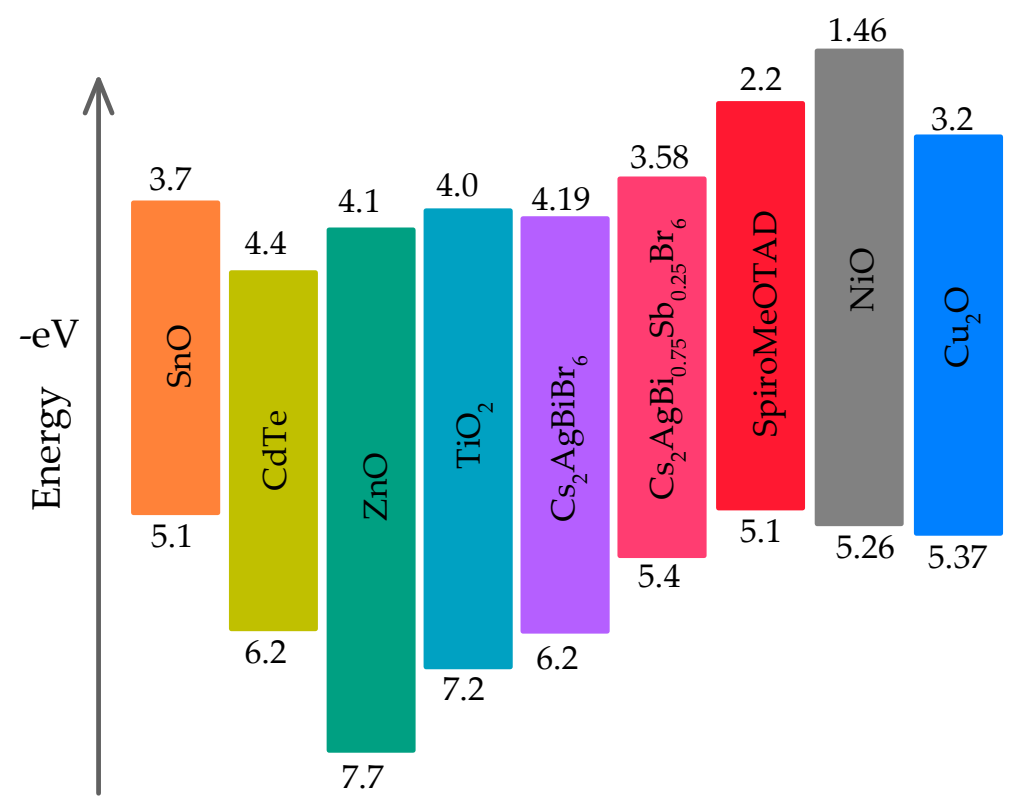

Figure 9. Schematic of the energy levels of two halide double perovskites with various ETMs and HTMs [51,55-57].

In addition to photovoltaic applications, halide double perovskites have been explored for photocatalytic applications. Recently, Zhou et al. [58] reported for the first time highly crystalline $\mathrm{Cs}_{2} \mathrm{AgBiBr}_{6}$ nanocrystals fabricated using a hot injection method. The $\mathrm{Cs}_{2} \mathrm{AgBiBr}_{6}$ nanocrystals exhibited impressive photoconversion of $\mathrm{CO}_{2}$ into solar fuels, with an electron consumption of $105 \mu \mathrm{mol} \mathrm{g}^{-1}$ in $6 \mathrm{~h}$. Most of the experimental studies on halide double perovskites have been based on the bulk synthesis of halide double perovskites. Research efforts can also be directed towards the fabrication other halide double perovskite nanocrystals. Volonakis et al. [59] investigated the photocatalytic capabilities of $\mathrm{Cs}_{2} \mathrm{AgBiBr}_{6}, \mathrm{Cs}_{2} \mathrm{AgBiCl}_{6}, \mathrm{Cs}_{2} \mathrm{AgSbBr}_{6}$, and $\mathrm{Cs}_{2} \mathrm{AgInCl}_{6}$ in water splitting. This discovery proves that the application of halide double perovskites can go beyond replacing hybrid lead halide in PSCs. Further efforts can be dedicated to screening more halide double perovskites for photocatalytic and optoelectronic applications. Table 3 gives a summary of some of the halide double perovskites that have been studied to date.

Table 3. Summary of some of the studied halide double perovskites showing space group, synthesis techniques, and bandgaps.

\begin{tabular}{|c|c|c|c|c|c|}
\hline Perovskite & Space Group & Synthesis Route & $\begin{array}{l}\text { Bandgap (Measured/ } \\
\text { Theoretical eV) }\end{array}$ & PCE\% & References \\
\hline \multirow{2}{*}{$\mathrm{Cs}_{2} \mathrm{AgInCl}_{6}$} & $F m 3 m$ & Solvent evaporation & $3.3 / 2.7 \pm 0.6$ & - & [31] \\
\hline & $F m 3 m$ & Hydrothermal & $3.23 / 3.33$ & - & {$[60]$} \\
\hline \multirow{3}{*}{$\mathrm{Cs}_{2} \mathrm{AgBiCl}_{6}$} & $F m 3 m$ & Solvent evaporation & $2.77 / 2.62$ & - & {$[36]$} \\
\hline & $F m 3 m$ & Solid state & $2.2 / 2.4$ & - & {$[34]$} \\
\hline & $F m 3 m$ & $\begin{array}{l}\text { Solid state/solvent } \\
\text { evaporation }\end{array}$ & $2.4 /-$ & - & [61] \\
\hline \multirow{6}{*}{${ }^{1} \mathrm{Cs}_{2} \mathrm{AgBiBr}_{6}$} & $F m 3 m$ & Solvent evaporation & $2.19 / 2.06$ & - & {$[36]$} \\
\hline & $F m 3 m$ & Solid state & $1.9 / 1.8$ & - & [34] \\
\hline & $F m 3 m$ & Solid cooling & $1.95 /-$ & - & [35] \\
\hline & $F m 3 m$ & $\begin{array}{l}\text { Solid state/solvent } \\
\text { evaporation }\end{array}$ & $1.8 /-$ & - & [61] \\
\hline & $F m 3 m$ & Hydrothermal & $2.05 /-$ & 1.22 & [51] \\
\hline & $F m 3 m$ & Hydrothermal & - & 1.44 & [52] \\
\hline
\end{tabular}


Table 3. Cont.

\begin{tabular}{cccccc}
\hline Perovskite & Space Group & Synthesis Route & $\begin{array}{c}\text { Bandgap (Measured/ } \\
\text { Theoretical eV) }\end{array}$ & PCE\% & References \\
\hline $\mathrm{Cs}_{2} \mathrm{AgBiI}_{6}$ & $F m 3 m$ & - & $-/ 1.6$ & - & {$[34]$} \\
$\mathrm{Cs}_{2} \mathrm{AuBiCl}_{6}$ & $F m 3 m$ & - & $-/ 1.6$ & - & {$[34]$} \\
$\mathrm{Cs}_{2} \mathrm{AuBiBr}_{6}$ & $F m 3 m$ & - & $-/ 1.1$ & - & {$[34]$} \\
$\mathrm{Cs}_{2} \mathrm{AuBiI}_{6}$ & $F m 3 m$ & - & $-/ 0.5$ & - & {$[34]$} \\
$\mathrm{Cs}_{2} \mathrm{CuBiCl}_{6}$ & $F m 3 m$ & - & $-/ 2.0$ & - & {$[34]$} \\
$\mathrm{Cs}_{2} \mathrm{CuBiBr}_{6}$ & $F m 3 m$ & - & $-/ 1.9$ & - & {$[34]$} \\
$\mathrm{Cs}_{2} \mathrm{CuBiI}_{6}$ & $F m 3 m$ & - & $-/ 1.3$ & - & {$[34]$} \\
$\mathrm{Cs}_{2} \mathrm{AgInBr}_{6}$ & $F m 3 m$ & - & $-/ 1.50$ & - & {$[33]$} \\
$\mathrm{Rb}_{2} \mathrm{AgInCl}_{6}$ & $F m 3 m$ & - & $-/ 2.5$ & - & {$[33]$} \\
$\mathrm{Rb}_{2} \mathrm{AgInBr}_{6}$ & $F m 3 m$ & - & $-/ 1.46$ & - & {$[33]$} \\
$\mathrm{Rb}_{2} \mathrm{CuInCl}_{6}$ & $F m 3 m$ & - & $-/ 1.36$ & - & {$[33]$} \\
$\mathrm{Rb}_{2} \mathrm{CuInBr}_{6}$ & $F m 3 m$ & - & $-/ 0.63$ & - & {$[33]$} \\
$\mathrm{Cs}_{2} \mathrm{Au}^{\mathrm{I}} \mathrm{Au}^{\mathrm{III}} \mathrm{Cl}_{6}$ & $I 4 / m m m$ & Solid state & $2.04 /-$ & - & {$[62,63]$} \\
$\mathrm{Cs}_{2} \mathrm{Au} \mathrm{Au}^{\mathrm{III}} \mathrm{Br}_{6}$ & $I 4 / m m m$ & Solid state & $1.31 /-$ & - & {$[63-65]$} \\
$\mathrm{Cs}_{2} \mathrm{Au}^{\mathrm{I}} \mathrm{Au}^{\mathrm{III}} \mathrm{I}_{6}$ & $I 4 / m m m$ & Solid state & $1.60 /-$ & - & {$[63,64]$} \\
$(\mathrm{MA})_{2} \mathrm{AgBiBr}_{6}$ & $F m 3 m$ & Hydrothermal & $2.0 / 2.02$ & - & {$[39]$} \\
$(\mathrm{MA})_{2} \mathrm{KBiCl}_{6}$ & $R 3 m$ & Hydrothermal & $3.04 / 3.08$ & - & {$[38]$} \\
$(\mathrm{MA})_{2} \mathrm{AgSbI}_{6}$ & $R 3 m$ & Solid state & $1.93 / 2.12$ & - & {$[50]$} \\
\hline
\end{tabular}

\section{Conclusions}

This review focused on the structural, stability, and optical properties of halide double perovskites. Most of the studied double perovskites crystallized into 3D structures and exhibited better stability than hybrid lead halide perovskites. This may be attributed to the replacement of organic cations $\left(\mathrm{FA}^{+}, \mathrm{MA}^{+}\right)$with an inorganic cation, $\mathrm{Cs}^{+}$. However, the present levels of stability in PSCs still require encapsulation to prevent degradation; thus, more research is needed to produce truly effective and stable halide double perovskites. Most of the reported halide double perovskites have exhibited indirect and wide bandgaps, which are not suitable for solar photovoltaic applications. A few of the halide double perovskites such as $\mathrm{Cs}_{2} \mathrm{InAgCl}_{6}$ have direct bandgaps and can be employed in tandem solar cells since they have wide bandgaps. Perhaps investigating other trivalent cations such as lanthanide $3^{+}$cations would produce more promising results. To the best of our knowledge, only the $\mathrm{Cs}_{2} \mathrm{AgBiBr}_{6}$ halide double perovskite has been employed as a light absorber in planar heterojunction solar cells, exhibiting PCE of about $1 \%$. Considering that most halide double perovskites have wide bandgaps, investigating the performance of these halide double perovskites in tandem solar cells might produce promising results. They can also be explored in photocatalytic application. However, presently halide double perovskites might not be adequate replacements for hybrid lead halide perovskites in single junction solar cells.

Author Contributions: Conceptualization, D.M. and R.T.; Writing-Review \& Editing, D.M. and N.Z.; Visualization, D.M.; Supervision, R.T. and E.M.; Funding Acquisition, E.M.

Funding: This research was funded by South African National Research Foundation (NRF) and Department of Science and Technology (DST).

Acknowledgments: We are grateful for financial support from our sponsors South African NRF, Govani Beki Research and Development Centre (GMRDC) of the University of Fort Hare and Eskom tertiary education support (TESP).

Conflicts of Interest: The authors declare no conflict of interest.

\section{References}

1. Ameen, S.; Rub, M.A.; Kosa, S.A.; Alamry, K.A.; Akhtar, M.S.; Shin, H.S.; Seo, H.K.; Asiri, A.M.; Nazeeruddin, M.K. Perovskite Solar Cells: Influence of Hole Transporting Materials on Power Conversion Efficiency. ChemSusChem 2016, 9, 10-27. [CrossRef] [PubMed] 
2. Hicks, W. Solar Cell Efficiency Explanatory Notes. Available online: https:/ /www.nrel.gov/news/features/ 2018/nrel-research-pushes-perovskites-closer-to-market.html (accessed on 18 May 2018).

3. Demic, S.; Ozcivan, A.N.; Can, M.; Ozbek, C.; Karakaya, M. Recent Progresses in Perovskite Solar Cells. In Nanostructured Solar Cells; Das, N., Ed.; Intech: Rijeka, Croatia, 2017; pp. 277-304, ISBN 9783902613042.

4. Srivastava, R. Perovskite as Light Harvester: Prospects, Efficiency, Pitfalls and Roadmap. In Nanostructured Solar Cells; Das, N., Ed.; Intech: Rijeka, Croatia, 2017; pp. 245-276, ISBN 978-953-51-2936-3.

5. Ibn-Mohammed, T.; Koh, S.C.L.; Reaney, I.M.; Acquaye, A.; Schileo, G.; Mustapha, K.B. Perovskite Solar Cells: An Integrated Hybrid Lifecycle Assessment and Review in Comparison with Other Photovoltaic Technologies. Renew. Sustain. Energy Rev. 2017, 80, 1321-1344. [CrossRef]

6. Salim, T.; Sun, S.; Abe, Y.; Krishna, A.; Grimsdale, A.; Lam, Y.M. Perovskite-Based Solar Cells: Impact of Morphology and Device Architecture on Device Performance. J. Mater. Chem. A 2015, 3, 8943-8969. [CrossRef]

7. Yu, Z.; Sun, L. Recent Progress on Hole-Transporting Materials for Emerging Organometal Halide Perovskite Solar Cells. Adv. Energy Mater. 2015, 5, 1-17. [CrossRef]

8. Asghar, M.I.; Zhang, J.; Wang, H.; Lund, P.D. Device Stability of Perovskite Solar Cells-A Review. Renew. Sustain. Energy Rev. 2017, 77, 131-146. [CrossRef]

9. Papanikolaou, N.C.; Hatzidaki, E.G.; Belivanis, S.; Tzanakakis, G.N.; Tsatsakis, A.M. Lead Toxicity Update. A Brief Review. Med. Sci. Monit. 2005, 11, RA329-RA336. [PubMed]

10. Qiu, L.; Ono, L.K.; Qi, Y. Advances and Challenges to the Commercialization of Organic-Inorganic Halide Perovskite Solar Cell Technology. Mater. Today Energy 2018, 7, 169-189. [CrossRef]

11. Assi, M.A.; Hezmee, M.N.M.; Haron, A.W.; Sabri, M.Y.; Rajion, M.A. The Detrimental Effects of Lead on Human and Animal Health. Vet. World 2016, 9, 660-671. [CrossRef] [PubMed]

12. Abdullahi, M.S. Toxic Effects of Lead in Humans: An overview. J. Sci. Toxicol. 2013, 2, 157-162.

13. Babayigit, A.; Thanh, D.D.; Ethirajan, A.; Manca, J.; Muller, M.; Boyen, H.G.; Conings, B. Assessing the Toxicity of Pb- and Sn- Based Perovskite Solar Cells in Model Organism Danio rerio. Sci. Rep. 2016, 6, 1-11. [CrossRef] [PubMed]

14. Babayigit, A.; Ethirajan, A.; Muller, M.; Conings, B. Toxicity of organometal halide perovskite solar cells. Nat. Mater. 2016, 15, 247-251. [CrossRef] [PubMed]

15. Lyu, M.; Yun, J.H.; Cai, M.; Jiao, Y.; Bernhardt, P.V.; Zhang, M.; Wang, Q.; Du, A.; Wang, H.; Liu, G.; et al. Organic Inorganic Bismuth(III)-based Material: A Lead-Free, Air-Stable and Solution-Processable Light-Absorber Beyond Organolead Perovskites. Nano Res. 2016, 9, 692-702. [CrossRef]

16. Zhu, H.X.; Liu, J.M. Electronic Structure of Organometal Halide Perovskite $\mathrm{CH}_{3} \mathrm{NH}_{3} \mathrm{BiI}_{3}$ and Optical Absorption Extending to Infrared Region. Sci. Rep. 2016, 6, 2812-2824. [CrossRef] [PubMed]

17. Xiao, Z.; Meng, W.; Wang, J.; Mitzi, D.B.; Yan, Y. Searching for Promising New Perovskite-based Photovoltaic Absorbers: The Importance of Electronic Dimensionality. Mater. Horizons 2017, 4, 206-216. [CrossRef]

18. Park, B.; Philippe, B.; Zhang, X.; Rensmo, H.; Boschloo, G.; Johansson, E.M. Bismuth Based Hybrid Perovskites $\mathrm{A}_{3} \mathrm{Bi}_{2} \mathrm{I}_{9}$ (A: Methylammonium or Cesium) for Solar Cell Application. Adv. Mater. Matter 2015, 27, 6806-6813. [CrossRef] [PubMed]

19. Zhang, Z.; Li, X.; Xia, X.; Wang, Z.; Huang, Z.; Lei, B.; Gao, Y. High-Quality $\left(\mathrm{CH}_{3} \mathrm{NH}_{3}\right)_{3} \mathrm{Bi}_{2} \mathrm{I}_{9}$ Film-Based Solar Cells: Pushing Efficiency up to 1.64\%. J. Phys. Chem. Lett. 2017, 8, 4300-4307. [CrossRef] [PubMed]

20. Xiao, Z.; Du, K.Z.; Meng, W.; Wang, J.; Mitzi, D.B.; Yan, Y. Intrinsic Instability of $\mathrm{Cs}_{2} \operatorname{In}(\mathrm{I}) \mathrm{M}(\mathrm{III}) \mathrm{X}_{6}(\mathrm{M}=\mathrm{Bi}$, Sb; $\mathrm{X}=$ Halogen) Double Perovskites: A Combined Density Functional Theory and Experimental Study. J. Am. Chem. Soc. 2017, 139, 6054-6057. [CrossRef] [PubMed]

21. Lozhkina, O.A.; Murashkina, A.A.; Elizarov, M.S.; Shilovskikh, V.V.; Zolotarev, A.A.; Kapitonov, Y.V. Microstructural Analysis and Optical Properties of the Halide Double Perovskite $\mathrm{Cs}_{2} \mathrm{BiAgBr}_{6} \mathrm{Single}_{\text {Crystals. }}$ Chem. Phys. Lett. 2018, 694, 18-22. [CrossRef]

22. Ghebouli, M.A.; Chihi, T.; Ghebouli, B.; Fatmi, M. Study of the Structural, Elastic, Electronic and Optical Properties of Lead-free Halide Double Perovskites $\mathrm{Cs}_{2} \mathrm{AgBiX}_{6}(\mathrm{X}=\mathrm{Br}, \mathrm{Cl})$. Chin. J. Phys. 2018, 56, 323-330. [CrossRef]

23. Dong, L.; Sun, S.; Deng, Z.; Li, W.; Wei, F.; Qi, Y.; Li, Y.; Li, X.; Lu, P.; Ramamurty, U. Elastic Properties and Thermal Expansion of Lead-free Halide Double $\mathrm{Cs}_{2} \mathrm{AgBiBr}_{6}$. Comput. Mater. Sci. 2018, 141, 49-58. [CrossRef]

24. Yin, W.; Shi, T.; Yan, Y. Unique Properties of Halide Perovskites as Possible Origins of the Superior Solar Cell Performance. Adv. Mater. Matter 2014, 26, 4653-4658. [CrossRef] [PubMed] 
25. Brandt, R.E.; Stevanovi, V.; Ginley, D.S.; Buonassisi, T. Identifying Defect-Tolerant Semiconductors with High Minority-Carrier Lifetimes: Beyond Hybrid Lead Halide Perovskites. MRS Commun. 2015, 5, 265-275. [CrossRef]

26. Manser, J.S.; Christians, A.; Kamat, P.V. Intriguing Optoelectronic Properties of Metal Halide Perovskites. Chem. Rev. 2016, 116, 12956-13008. [CrossRef] [PubMed]

27. Zhao, X.; Yang, J.; Fu, Y.; Yang, D.; Xu, Q.; Yu, L.; Wei, S.; Zhang, L. Design of Lead-Free Inorganic Halide Perovskites for Solar Cells via. J. Am. Chem. Soc. 2017, 139, 2630-2638. [CrossRef] [PubMed]

28. Djurisic, A.; Liu, F.; Tam, H.; Wong, M.; Ng, A.; Surya, C.; Chen, W.; He, Z. Perovskite Solar Cells-An Overview of Critical Issues. Prog. Quantum Electron. 2017, 53, 1-37. [CrossRef]

29. Hoefler, S.F.; Trimmel, G.; Rath, T. Progress on Lead-Free Metal Halide Perovskites for Photovoltaic Applications: A review. Monatsh. Chem. 2017, 148, 795-826. [CrossRef] [PubMed]

30. Morss, L.R.; Siegal, M.; Stenger, L.; Edelstein, N. Preparation of Cubic Chloro Complex Compounds of Trivalent Metals: $\mathrm{Cs}_{2} \mathrm{NaMCl}_{6}$. Inorg. Chem. 1970, 9, 1771-1775. [CrossRef]

31. Volonakis, G.; Haghighirad, A.A.; Milot, R.L.; Sio, W.H.; Filip, M.R.; Wenger, B.; Johnston, M.B.; Herz, L.M.; Snaith, H.J.; Giustino, F. $\mathrm{Cs}_{2} \mathrm{InAgCl}_{6}$ : A New Lead-Free Halide Double Perovskite with Direct Band Gap. J. Phys. Chem. Lett. 2017, 8, 772-778. [CrossRef] [PubMed]

32. Shannon, R. Revised Effective Ionic Radii and Systematic Studies of Interatomic Distances in Halide and Chalcogenides. Acta Crystallogr. Sect. A 1976, 32, 751-767. [CrossRef]

33. Zhao, X.G.; Yang, D.; Sun, Y.; Li, T.; Zhang, L.; Yu, L.; Zunger, A. Cu-In Halide Perovskite Solar Absorbers. J. Am. Chem. Soc. 2017, 139, 6718-6725. [CrossRef] [PubMed]

34. Volonakis, G.; Filip, M.R.; Haghighirad, A.A.; Sakai, N.; Wenger, B.; Snaith, H.J.; Giustino, F. Lead-Free Halide Double Perovskites via Heterovalent Substitution of Noble Metals. J. Phys. Chem. Lett. 2016, 7, 1254-1259. [CrossRef] [PubMed]

35. Slavney, A.H.; Hu, T.; Lindenberg, A.M.; Karunadasa, H.I. A Bismuth-Halide Double Perovskite with Long Carrier Recombination Lifetime for Photovoltaic Applications. J. Am. Chem. Soc. 2016, 138, 2138-2141. [CrossRef] [PubMed]

36. McClure, E.T.; Ball, M.R.; Windl, W.; Woodward, P.M. $\mathrm{Cs}_{2} \mathrm{AgBiX}_{6}(\mathrm{X}=\mathrm{Br}, \mathrm{Cl})$ : New Visible Light Absorbing, Lead-Free Halide Perovskite Semiconductors. Chem. Mater. 2016, 28, 1348-1354. [CrossRef]

37. Vasala, S.; Karppinen, M. $\mathrm{A}_{2} \mathrm{~B}^{\prime} B^{\prime \prime} \mathrm{O}_{6}$ perovskites: A review. Prog. Solid State Chem. 2015, 43, 1-36. [CrossRef]

38. Wei, F.; Deng, Z.; Sun, S.; Xie, F.; Kieslich, G.; Evans, D.; Carpenter, M.; Bristowe, P.; Cheetham, A. The Synthesis, Structure and Electronic Properties of a Lead-Free Hybrid Inorganic-Organic Double Perovskite $(\mathrm{MA})_{2} \mathrm{KBiCl}_{6}$ (MA = methylammonium). Mater. Horizons 2016, 3, 328-332. [CrossRef]

39. Wei, F.; Deng, Z.; Sun, S.; Zhang, F.; Evans, D.M.; Kieslich, G.; Tominaka, S.; Carpenter, M.A.; Zhang, J.; Bristowe, P.D.; et al. Synthesis and Properties of a Lead-Free Hybrid Double Perovskite: $\left(\mathrm{CH}_{3} \mathrm{NH}_{3}\right)_{2} \mathrm{AgBiBr}_{6}$. Chem. Mater. 2017, 29, 1089-1094. [CrossRef]

40. Deng, Z.; Wei, F.; Sun, S.; Kieslich, G.; Cheetham, A.K.; Bristowe, P.D. Exploring the Properties of Lead-Free Hybrid Double Perovskites Using a Combined Computational-Experimental Approach. J. Mater. Chem. A 2016, 4, 12025-12029. [CrossRef]

41. Cvjetko, P.; Cvjetko, I.; Pavlica, M. Thallium Toxicity in Humans. Arh. Hig. Rada Toksikol. 2010, 61, 111-119. [CrossRef] [PubMed]

42. Smith, I.C.; Hoke, E.T.; Solis-Ibarra, D.; Mcgehee, M.D.; Karunadasa, H.I.A. Layered Hybrid Perovskite Solar-Cell Absorber with Enhanced Moisture Stability. Angew. Chem. 2014, 53, 11232-11235. [CrossRef] [PubMed]

43. Slavney, A.H.; Smaha, R.W.; Smith, I.C.; Jaffe, A.; Umeyama, D.; Karunadasa, H.I. Chemical Approaches to Addressing the Instability and Toxicity of Lead-Halide Perovskite Absorbers. Inorg. Chem. 2016, 56, 46-55. [CrossRef] [PubMed]

44. Zhao, S.; Yamamoto, K.; Iikubo, S.; Hayase, S.; Ma, T. First-Principles Study of Electronic and Optical Properties of Lead-Free Double Perovskites $\mathrm{Cs}_{2} \mathrm{NaBX}_{6}(\mathrm{~B}=\mathrm{Sb}, \mathrm{Bi} ; \mathrm{X}=\mathrm{Cl}, \mathrm{Br}, \mathrm{I})$. J. Phys. Chem. Solids 2018, 117, 117-121. [CrossRef]

45. Li, B.; Li, Y.; Zheng, C.; Gao, D. Advancements in the Stability of Perovskite Solar Cells: Degradation Mechanisms and Improvements Approaches. RSC Adv. 2016, 6, 38079-38091. [CrossRef] 
46. Shirayama, M.; Kato, M.; Miyadera, T.; Sugita, T.; Fujiseki, T.; Hara, S.; Kadowaki, H.; Murata, D.; Chikamatsu, M.; Fujiwara, H. Degradation Mechanism of $\mathrm{CH}_{3} \mathrm{NH}_{3} \mathrm{PbI}_{3}$ Perovskite Materials Upon Exposure to Humid Air. J. Appl. Phys. 2016, 119, 115501. [CrossRef]

47. Savory, C.N.; Walsh, A.; Scanlon, D.O. Can Pb-Free Halide Double Perovskites Support High-Efficiency Solar Cells? ACS Energy Lett. 2016, 1, 949-955. [CrossRef] [PubMed]

48. Sutton, R.; Eperon, G.E.; Miranda, L.; Parrott, E.S.; Kamino, B.; Patel, J.B.; Horantner, M.; Johnston, M.; Haghighirad, A.A.; Moore, D.; et al. Bandgap-Tunable Cesium Lead Halide Perovskites with High Thermal Stability fo Efficient Solar Cells. Adv. Energy Mater. 2016, 6, 1502458. [CrossRef]

49. Niu, G.; Li, W.; Li, J.; Liang, X.; Wang, L. Enhancement of Thermal Stability for Perovskite Solar Cells Through Cesium Doping. RSC Adv. 2017, 7, 17473-17479. [CrossRef]

50. Li, Y.; Wu, T.; Sun, L.; Yang, R.; Jiang, L.; Cheng, P.; Hao, Q.; Wang, T.; Lu, R.; Deng, W. Lead-Free and Stable Antimony-Silver-Halide Double Perovskite $\left(\mathrm{CH}_{3} \mathrm{NH}_{3}\right)_{2} \mathrm{AgSbI}_{6}$. Advances 2017, 7, 35175-35180. [CrossRef]

51. Wu, C.; Zhang, Q.; Liu, Y.; Luo, W.; Guo, X.; Huang, Z.; Ting, H.; Sun, W.; Zhong, X.; Wei, S.; et al. The Dawn of Lead-Free Perovskite Solar Cell: Highly Stable Double Perovskite $\mathrm{Cs}_{2} \mathrm{AgBiBr}_{6}$ Film. Adv. Sci. 2017, 5, 1700759. [CrossRef] [PubMed]

52. Ning, W.; Wang, F.; Wu, B.; Lu, J.; Yan, Z.; Liu, X.; Tao, Y. Long Electron-Hole Diffusion Length in High-Quality Lead-Free Double Perovskite Films. Adv. Mater. 2018, 30, 1-6. [CrossRef] [PubMed]

53. Kim, J.; Kim, G.; Kim, T.K.; Kwon, S.; Back, H.; Lee, J.; Lee, S.H.; Kangb, H.; Lee, K. Efficient planar-heterojunction perovskite solar cells achieved via interfacial modification of a sol-gel ZnO electron collection layer. J. Mater. Chem. A 2014, 41, 17291-17296. [CrossRef]

54. Slavney, A.H.; Leppert, L.; Bartesaghi, D.; Gold-parker, A.; Toney, M.F.; Savenije, T.J.; Neaton, B.; Karunadasa, H.I. Defect-Induced Band-Edge Reconstruction of a Bismuth-Halide Double Perovskite for Visible-Light Absorption. J. Am. Chem. Soc. 2017, 139, 5015-5018. [CrossRef] [PubMed]

55. Du, K.; Meng, W.; Wang, X.; Yan, Y.; Mitzi, D.B. Double Perovskites Bandgap Engineering of Lead-Free Double Perovskite $\mathrm{Cs}_{2} \mathrm{AgBiBr}_{6}$ through Trivalent Metal Alloying. Angew. Chem. Int. Ed. 2017, 56, 8158-8162. [CrossRef] [PubMed]

56. Deng, Q.; Li, Y.; Chen, L.; Wang, S.; Wang, G.; Sheng, Y.; Shao, G. The Effects of Electron and Hole Transport Layer with the Electrode Work Function on Perovskite Solar Cells. Mod. Phys. Lett. B 2016, 30, 1-10. [CrossRef]

57. Mahmood, K.; Sarwar, S.; Mehran, M.T. Current Status of Electron Transport Layers in Perovskite Solar Cells: Materials and Properties. RSC Adv. 2017, 7, 17044-17062. [CrossRef]

58. Zhou, L.; Xu, Y.F.; Chen, B.X.; Kuang, D.B.; Su, C.Y. Synthesis and Photocatalytic Application of Stable Lead. Small 2018, 14, 1-7. [CrossRef] [PubMed]

59. Volonakis, G.; Giustino, F. Surface Properties of Lead-Free Halide Double Perovskites: Possible Visible-Light Photo-Catalysts for Water Splitting. Appl. Phys. Lett. 2018, 112, 1-5. [CrossRef]

60. Zhou, J.; Xia, Z.; Molokeev, M.S.; Zhang, X.; Peng, D.; Liu, Q. Composition Design, Optical Gap and Stability Investigations of Lead-Free Halide Double Perovskite $\mathrm{Cs}_{2} \mathrm{AgInCl}_{6}$. J. Mater. Chem. A 2017, 5, 15031-15037. [CrossRef]

61. Filip, M.R.; Hillman, S.; Haghighirad, A.A.; Snaith, H.J.; Giustino, F. Band Gaps of the Lead-Free Halide Double Perovskites $\mathrm{Cs}_{2} \mathrm{BiAgCl}_{6}$ and $\mathrm{Cs}_{2} \mathrm{BiAgBr}_{6}$ from Theory and Experiment. J. Phys. Chem. Lett. 2016, 7 , 2579-2585. [CrossRef] [PubMed]

62. Elliott, N.; Pauling, L. The Crystal Structure of Cesium Aurous Auric Chloride, $\mathrm{Cs}_{2} \mathrm{AuAuCl}_{6}$, and Cesium. J. Am. Chem. Soc. 1938, 60, 1846-1851. [CrossRef]

63. Liu, X.J.; Matsuda, K.; Moritomo, Y.; Nakamura, A.; Kojima, N. Electronic Structure of the Gold Complexes $\mathrm{Cs}_{2} \mathrm{Au}_{2} \mathrm{X}_{6}(\mathrm{X}=\mathrm{I}, \mathrm{Br}$, and Cl). Phys. Rev. B 1999, 59, 7925. [CrossRef]

64. Riggs, S.C.; Shapiro, M.C.; Corredor, F.; Geballe, T.H.; Fisher, I.R.; Mccandless, G.T.; Chan, J.Y. Single Crystal Growth by Self-Flux Method of the Mixed Valence Gold Halides. J. Cryst. Growth 2012, 355, 13-16. [CrossRef]

65. Matsushita, N.; Kitagawa, H.; Kojima, N. A Three-Dimensional Iodo-Bridged Mixed-Valence Gold(I, III) Compound, $\mathrm{Cs}_{2} \mathrm{AuIAuIIII}_{6}$. Acta Crystallogr. Sect. C 1997, C53, 663-666. [CrossRef]

(C) 2018 by the authors. Licensee MDPI, Basel, Switzerland. This article is an open access article distributed under the terms and conditions of the Creative Commons Attribution (CC BY) license (http:/ / creativecommons.org/licenses/by/4.0/). 